\title{
New records of ants (Hymenoptera: Formicidae) for Colombia
}

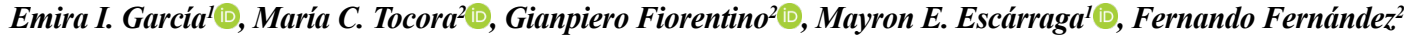

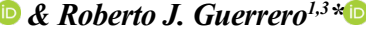 \\ ${ }^{1}$ Universidad del Magdalena, Facultad de Ciencias Básicas, Programa de Biología, Santa Marta, Magdalena, Colombia \\ ${ }^{2}$ Universidad Nacional de Colombia Facultad de Ciencias, Instituto de Ciencias Naturales, Bogotá, Colombia. \\ ${ }^{3}$ Universidad del Magdalena, Centro de Colecciones Cientificas, Colecciones Biológicas, Santa Marta, Magdalena, \\ Colombia. \\ *Corresponding author: RobertoJ. Guerrero,e-mail: rguerrero@unimagdalena.edu.co
}

GARCÍA, E.I., TOCORA, M.C., FIORENTINO, G., ESCÁRRAGA, M.E., FERNÁNDEZ, F., GUERRERO, R.J. New records of ants (Hymenoptera: Formicidae) for Colombia. Biota Neotropica 20(4): e20201088. https:// doi.org/10.1590/1676-0611-BN-2020-1088

\begin{abstract}
Even though Colombia has high levels of ant species richness in the Neotropical region, this richness continues to increase. New records of the ant subfamilies Amblyoponinae, Dolichoderinae, Dorylinae, Myrmicinae, and Ponerinae are presented. Two species of Fulakora, two species of Azteca, one species of Cylindromyrmex, 25 species of Myrmicinae belonging to 12 genera (Acanthognathus, Basiceros, Daceton, Eurhopalothrix, Hylomyrma, Mycetomoellerius, Mycetophylax, Mycocepurus, Octostruma, Pheidole, Rogeria, and Talaridris), and one species of Leptogenys are registered for the first time for Colombia. Five species are new records for South America. For each species, the geographical distance of the record closest to the Colombian locality is offered. Several factors, such as access to previously unexplored conserved areas, sampling techniques that cover heterogeneous microhabitats such as leaf litter, and many more taxonomic researches have allowed the knowledge of ant fauna in Colombia to continue growing.
\end{abstract}

Keywords: Distribution range; Neotropical region; Pheidole; Species richness; South America.

\section{Nuevos registros de hormigas (Hymenoptera: Formicidae) para Colombia}

Resumen: Aunque Colombia tiene altos niveles de riqueza de especies de hormigas en la región neotropical, esta riqueza continúa aumentando. Se presentan nuevos registros de las subfamilias de hormigas Amblyoponinae, Dolichoderinae, Dorylinae, Myrmicinae y Ponerinae. Se registran por primera vez para Colombia, dos especies de Fulakora, dos especies de Azteca, una especie de Cylindromyrmex, 25 especies de Myrmicinae pertenecientes a 12 géneros (Acanthognathus, Basiceros, Daceton, Eurhopalothrix, Hylomyrma, Mycetomoellerius, Mycetophylax, Mycocepurus, Octostruma, Pheidole, Rogeria, y Talaridris), y una especie de Leptogenys. Cinco especies son nuevos registros para América del Sur. Para cada especie, se ofrece la distancia geográfica del registro más cercano a la localidad colombiana. Varios factores, como el acceso a áreas conservadas previamente inexploradas, las técnicas de muestreo que cubren microhábitats heterogéneos, como la hojarasca, y muchas más investigaciones taxonómicas han permitido que el conocimiento de la fauna de hormigas en Colombia continúe creciendo.

Palabras clave: Ámbito de distribución; Región Neotropical; Pheidole; Riqueza de especies; América del Sur. 


\section{Introduction}

Globally, 337 valid genera and 13,809 valid species of ants are known (Bolton 2020). With 105 genera and more than 1100 species, the ant fauna in Colombia is one of the richest in the World (Fernández et al. 2019). Some ant genera, however, are poorly represented in Colombia (e.g., Fulakora Mann, 1919) while others, such as Pheidole Westwood, 1839 exhibit high diversity (Fernández et al. 2019). Other taxonomic groups, such as the subfamily Martialinae Rabeling \& Verhaagh, 2008, and the genus Bothriomyrmex Emery, 1869, have yet to be found there. Because of this, Colombia ranks as the second most diverse Neotropical country, with a slightly lower ant genus richness than Brazil (105 vs 112 genera, respectively). The Colombian diversity, however, is relatively larger than Costa Rica's, whose myrmecofauna is much better known (Guerrero et al. 2018).

Recent field trips and routine curatorial activities in some major insect collections are helping to increase the knowledge of the ant fauna of this country. The recent ceasefire in Colombia has allowed field activities in areas that were previously too dangerous or areas under the protection of the National Parks Unit (Guerrero et al. 2018). This access to previously unsampled areas as the Colombian Amazon and forests in the Sierra Nevada de Santa Marta (northeastern Colombia) has allowed us to find 31 species of ants that we are registering for the first time for Colombia, and five of those ones are new records for South America.

\section{Materials and Methods}

The examined specimens come from the following collections: CATAC, Colección de Artrópodos Terrestres de la Amazonía Colombiana, Instituto SINCHI, Leticia, Colombia; CBUMAG, Colecciones Biológicas de la Universidad del Magdalena, Santa Marta, Colombia; ICN, Instituto de Ciencias Naturales, Universidad Nacional de Colombia, Bogotá D.C., Colombia; IAvH, Instituto de Investigación de Recursos Biológicos Alexander von Humboldt, Villa de Leyva, Colombia; and MPUJ, Colección entomológica de la Universidad Pontificia Javeriana, Bogotá D.C., Colombia. The samples were mounted and examined using diverse stereomicroscopes (Leica Wild m3c, Motic SMZ-168 and Carl Zeiss Stemmi 305) at magnifications of $60-80 x$.

The distance between the record in Colombia and the one in the nearest country was calculated with https://www.gps-coordinates. net/distance by calculating the straight line spacing between the geographic coordinates of both records. When a species has more than one record for Colombia, the Colombian record closest to the record in the neighboring country was used. The closest record to Colombia was extracted from electronic resources, such as antmaps. org (Janicki et al. 2016) and www.antweb.org, and in some cases from the original descriptions (e.g., Lattke, 1992). In the case of Antweb information, we record the specimen identifier (e.g., the FMNHINS0000095938 specimen of Eurhopalothrix schmidti (Menozzi, 1936) is the closest record to Colombia). In all cases, the distance is presented in kilometers.

\section{Results}

\section{Taxa richness}

We identified 31 species of ants not reported from Colombia. These species are distributed among five subfamilies and 16 genera. The subfamily that contained the largest number of new records was Myrmicinae, with 12 genera, of which Pheidole with ten species, was the richest. The other subfamilies had only one or two new recorded species. We found only one genus in each of the following subfamilies: Amblyoponinae, Dolichoderinae, Dorylinae and Ponerinae.

\section{Checklist of new ant records for Colombia}

\section{Amblyoponinae}

Fulakora agostii Lacau \& Delabie, 2002

Material Examined. 1 worker. Colombia: Quindío: Armenia: Quindío University reserve, 4³3’15”N 75³9'40”W, 28/30-VIII-2009, squid bait, Martínez col. (ICN); 1 worker. Colombia: Cundinamarca: Quipile: El Tiber. Fca. Venecia. 0442'12" N 74³3'56” W. 1523 m. Winkler Cafetal. 15-IX.2011. J. Cepeda, C. Cantor, R. Martinez Leg. 2 workers. Colombia: Cundinamarca: Quipile: El Tiber. Fca. La Aldea. 0443’20” N 74³3'30” W. 1663 m. Winkler Cafetal. 17-IX.2011. J. Cepeda, C. Cantor, R. Martinez Leg.

Comments. Lacau \& Delabie (2002) described Fulakora agostii based on 12 workers collected in Bahia, Brazil. Posteriorly Munoz (2018) recorded this species in Paraná, Brazil. The present record extends the distribution of $F$. agostii $4592 \mathrm{Km}$ to the Northwest from the northernmost record in Bahia by Lacau \& Delabie (2002).

\section{Fulakora armigera Mayr, 1887}

Material Examined. 1 queen. Colombia: Amazonas: Leticia: Community Monifue Amena, BTF, 120 m, 408'30'S 6955'23”W, 12-XII-2002, floor forest, Rodríguez col. (MPUJ).

Comments. Mayr (1887) first described F. armigera from Santa Catarina, Brazil. This species has since been sampled extensively in the southeast coast in Brazil and has been reported for Argentina (Bruch 1921). The present record extends the distribution of $F$. armigera $1984.47 \mathrm{~km}$ to the West from the closest record in Brazil recorded by Lattke (1985). The Venezuelan records (Lattke 1985) for F. armigera are a case of mistaken identity (Lattke, pers. comm.) as they later were identified as an undescribed species, F. lurilabes (Lattke 1991).

\section{Dolichoderinae \\ Azteca quadraticeps Longino, 2007}

Material Examined. 2 queens. Colombia: Magdalena: Santa Marta: Universidad del Magdalena campus, 11¹3'30'N 74¹1'06”W, 2017, manual sampling, R. J. Guerrero col. (CBUMAG); 2 males. Same data (CBUMAG). 
Comments. This species was described from Costa Rica and later reported in Nicaragua (Longino 2007, 2013c). This is the first record of A. quadraticeps for South America, in the urban area of Santa Marta, northern Colombia. The present record extends the distribution of $A$. quadraticeps $1021 \mathrm{Km}$ to the East from the closest record in Limón, Costa Rica, reported by Longino (2007).

\section{Azteca snellingi Guerrero et al. 2010}

Material Examined. 4 major workers. Colombia: Magdalena: Santa Marta: Bonda, Paso del Mango, Reserva Caoba, 300 m, $11^{\circ} 11^{\prime} 50.28$ ”N 7406'5.4”W, 09-XI-2019, manual sampling, M. Escárraga col. (CBUMAG); 1 minor worker. Same data (CBUMAG).

Comments. This species was described and exclusively known from Panama (Guerrero et al. 2010, Basset et al. 2012, Ribeiro et al. 2013). This is the first record of $A$. snellingi for South America. The present record in an area of dry forest in the foothills of the Sierra Nevada de Santa Marta, extends the distribution of $A$. snellingi $677 \mathrm{Km}$ to the Northeast from the type locality.

\section{Dorylinae}

Cylindromyrmex brevitarsus Santschi, 1925

Material Examined. 1 queen. Colombia: Huila: PNN Cueva de los Guácharos, Cedros, 142'29.959”N 7608'51.521”W, XII-2006, W. Hernández col. (CBUMAG).

Comments. This species was previously known from Brazil, Costa Rica, Ecuador, Guatemala, México, Perú, Uruguay, and Venezuela (DeAndrade 2001, Branstetter \& Saenz 2012, Bezdeckova et al. 2015, Fernández \& Sendoya 2004). The present record is located $248 \mathrm{Km}$ to the North from the closest record in Sucumbíos (Ecuador) reported by de Andrade (2001).

\section{Myrmicinae}

Acanthognathus lentus Mann, 1922

Material Examined. 5 workers. Colombia: Vaupés: Mitú: km 2 via Monfort, $186 \mathrm{~m}, 1^{\circ} 14^{\prime} 05.1$ ”N 70¹2’57.8'W, 21-VII-2019, Winkler, N. Mazzi and L. Martínez col. (ICN).

Comments. This species was previously known from Brazil, Guyana, Honduras, and Suriname (Mann 1922, Brown \& Kempf 1969, Brandão 1991, Galvis \& Fernández 2009). The present record is located $1233 \mathrm{Km}$ to the Northwest from the closest record in Amazonas, Brazil reported by Kempf (1975).

\section{Basiceros militaris Weber, 1950}

Material Examined. 1 worker. Colombia: Vaupés: Villa Fátima, Cerro La Mujer, 273 m, 101'29.0”N 6958’34.8”W, 17/22-VIII-2019, Winkler, G. Fiorentino, A. Meneses and S. Ramírez col. (ICN).
Comments. This species was previously known from Venezuela, Ecuador, and Brazil (Bolton 1995, Brown 1960). The present record is located $710 \mathrm{Km}$ to the East from the closest record in the Yasuni National Park, Ecuador, reported by Mertl et al. (2012).

\section{Daceton boltoni Azorsa \& Sosa-Calvo, 2008}

Material Examined. 1 worker. Colombia: Amazonas: Leticia: Monifue Amena, $80 \mathrm{~m}, 4^{\circ} 6^{\prime}$ 'S $69^{\circ} 55^{\prime} \mathrm{W}, 24-\mathrm{IX}-2003$, corner sampling on tree, Vargas col. (MPUJ); 1 worker. Leticia: Monifue Amena, 70 m, 46'S 6955'W, 24-III-2004, Pitfall, D. Nariño col. (MPUJ); 1 worker. Leticia: Monifue Amena, $70 \mathrm{~m}, 4^{\circ} 6^{\prime}$ 'S 695 $55^{\prime} \mathrm{W}, 24-\mathrm{X}-2004$, manual sampling, E. Daza col. (MPUJ); 1 worker. Leticia: Monifue Amena, $70 \mathrm{~m}, 4^{\circ} 6^{\prime} \mathrm{S} 69^{\circ} 55^{\prime} \mathrm{W}, 23-\mathrm{X}-2004$, manual sampling, $\mathrm{M}$. Gallejo col. (MPUJ); 2 workers. Leticia: Monifue Amena, $70 \mathrm{~m}$, $4^{\circ} 6^{\prime} \mathrm{S} 69^{\circ} 55^{\prime} \mathrm{W}$; 04-X-2005, shaking, Beltrán col. (MPUJ); 1 worker. Leticia: Monifue Amena, $70 \mathrm{~m}, 4^{\circ} 6^{\prime} \mathrm{S} 69^{\circ} 55^{\prime} \mathrm{W}, 04-\mathrm{X}-2005$, pitfall, E. Daza col. (MPUJ).

Comments. This species was previously known from Iquitos (Peru), Manaus, and Mato Grosso, Brazil (Azorsa \& Sosa-Calvo 2008, Vicente et al. 2011). Therefore, this is the first record of $D$. boltoni in Colombia. This new record is in accordance with Azorsa \& Sosa-Calvo's (2008) presumption about Daceton species distribution patterns. The present record is located $340 \mathrm{Km}$ to the East from the type locality in Peru.

\section{Eurhopalothrix schmidti (Menozzi, 1936)}

Material Examined. 1 worker. Colombia: Santander: Encino: RN Encino, 2000 m, 0604'N 7307'W, Winkler, E. González col. (IAvH). No collection date.

Comments. Eurhopalothrix schmidti was previously known from Costa Rica, Nicaragua, and Panama (Longino 2013a, c, Antweb 2020). The present record is located $886 \mathrm{Km}$ to the Southeast from the closest record in Panama (Antweb: FMNHINS0000095938). This is the first South American record for this species.

\section{Eurhopalothrix xibalba Longino, 2013}

Material Examined. 2 workers. Colombia: Quindío: Filandia: Vda. Cruces, Fca. El Brasil, Corredor Pavas Bosque, $1850 \mathrm{~m}$, 441'17.41'N 75³6’32.81’'W, Winkler, E. Jiménez and E.L. Franco E.L. col. (IAvH); Filandia: Vda. Cruces, Fca. Los Micos Cañada 1 transecto, 1750 m, 441'14.42’'N 75³8'51.93’W, Winkler, E. Jiménez and E.L. Franco col. (IAvH). No dates for these localities.

Comments. This species has been reported from Mexico (Oaxaca), Guatemala, Honduras, Nicaragua, Costa Rica, Panama (Longino 2013a, Longino \& Branstetter 2018, Antweb 2020). The present record is located $555 \mathrm{Km}$ to the Southeast from the closest record in Panama (Antweb: CASENT0640577, CASENT0633025). This species is recorded for South America for the first time. 


\section{Hylomyrma longiscapa Kempf, 1961}

Material Examined. 2 workers. Colombia: Guainía: Inirida, Caño Sardina, 93 m, 357'20.1'N 6801'15.0”W, 19-III-2019, Winkler in mainland forest, D. Castro col. (ICN). 1 worker. Same data (CATAC).

Comments. This species is known from Brazil (Souza et al. 2015), Ecuador (Salazar et al. 2015), French Guiana (Fernández \& Sendoya 2004), Guyana (Fernández \& Sendoya 2004), and Suriname (Fernández $\&$ Sendoya 2004). The present record is located $1078 \mathrm{Km}$ to the closest record in Ecuador (Kempf 1975a).

\section{Mycetomoellerius relictus (Borgmeier, 1934)}

Material Examined. 2 workers. Colombia: Vaupés: Mitú, Trubon, 196 m, 1²'19.5'N 7003'70.5’'W, 24-III-2019, Flood Forest, D. Castro col. (ICN). 1 worker. Same data (CATAC).

Comments. This species has been previously reported multiple times in Brazil, French Guiana (Fernández \& Sendoya 2004), Guyana (Fernández \& Sendoya 2004), Peru, Suriname (Borgmeier 1934), Trinidad and Tobago (Weber 1968), and Venezuela (Mayhe-Nunes et al. 2002). The present record is located $1012 \mathrm{Km}$ to the Southwest from the closest record in Venezuela.

\section{Mycetophylax strigatus Mayr, 1887}

Material Examined. 1 worker. Colombia: Nariño: Orito: Territorio Kofán, $700 \mathrm{~m}, 0^{\circ} 30^{\prime} \mathrm{N} 77^{\circ} 13^{\prime} \mathrm{W}$, manual sampling, E. González col. (IAvH). No date.

Comments. This species was previously known from Panama and Brazil (Wheeler 1949, Kempf 1964). The present record is located 999 $\mathrm{Km}$ to the Southeast from the closest record in Panama, reported by Wheeler (1949) (Although this record was considered as questionable by Kempf [1964]), and $1939 \mathrm{Km}$ to the Northwest from the closest Brazilian record in the state of Amazonas, reported by Harada \& Adis (1998).

\section{Mycocepurus goeldii Forel, 1893}

Material Examined. 6 workers. Colombia: Cauca: Piamonte: Miraflor, $291 \mathrm{~m}, 1^{\circ} 1$ '46.25”N 76²6’31.18”W, VI-VII.2017, manual sampling, secondary forest, G. Delgado col. (ICN).

Comments. This species was previously known from Bolivia, Brazil, and Argentina (Kempf 1963, Mackay et al. 2004). The present record is located $1573 \mathrm{Km}$ to the Northwest from the closest record in the state of Acre, Brazil (Oliveira et al. 2009).

\section{Octostruma batesi (Emery, 1894)}

Material Examined. 2 workers. Colombia: Vaupés: Mitú: Trubon, $196 \mathrm{~m}, 1^{\circ} 12^{\prime} 19.5^{\prime \prime} \mathrm{N} 70^{\circ} 03^{\prime} 70.5$ 'W, 24-III-2019, leaf litter in floodplain forest, D. Castro col. (ICN). 1 queen. Same data as worker (ICN). 1 worker. Same data as worker and queen (CATAC).
Comments. This species was previously known from Bolivia (Longino 2013b), Brazil (Fernández \& Sendoya 2004), Ecuador (Longino 2013b), French Guiana (Fernández \& Sendoya 2004), Guyana (Fernández \& Sendoya 2004), Guatemala (Fernández \& Sendoya 2004), Panama (Fernández \& Sendoya 2004), Suriname (Fernández \& Sendoya 2004). The present record is located at approximately $788 \mathrm{Km}$ to the East from the closest record in Ecuador.

\section{Octostruma betschi Perrault, 1988}

Material Examined. 1 worker. Colombia: Vaupés: Mitú: Trubon, $196 \mathrm{~m}, 1^{\circ} 12^{\prime} 19.5^{\prime}{ }^{\prime} \mathrm{N} 70^{\circ} 03^{\prime} 70.5$ ' $\mathrm{W}, 24-\mathrm{III}-2019$, leaf litter in floodplain forest, D. Castro col. (ICN).

Comments. This species was previously known from Bolivia, Brazil, French Guiana (Perrault 1988) and Peru (Longino 2013b). The present record is located at approximately $1286 \mathrm{Km}$ to the West from the closest record in the state of Amazonas, Brazil.

\section{Octostruma excertirugis Longino, 2013}

Material Examined. 1 worker. Colombia: Santander: Cimitarra: Hacienda Ecológica Paraíso, 6²7’00.5’N 74¹7’07.0’W, 16/18-VII2019, Winkler. (ICN). No collector data.

Comments. This species was previously reported from Belize, Mexico, Guatemala, Honduras, Nicaragua, Costa Rica, Panama, and Ecuador (Longino 2013b, Antweb 2020). The present record is located $682 \mathrm{Km}$ to the East from the closest record in Panama (Antweb: MCZENT00511424).

\section{Pheidole bruchi Forel, 1914}

Material Examined. 1 soldier. Colombia: Cauca: Santa Rosa: Polígono 146, 2005 m, 166'14.7'N 7657'24.7’W, 22727-XI-2013, en tronco, Y.A Mera, D. Delgado, L. Ortiz, R. Sinisterra y C. Arturo col. (Unicauca); 2 workers. Same data (Unicauca); 2 soldiers. Santa Rosa: Polígono 146, $2020 \mathrm{~m}, 1^{\circ} 66^{\prime} 56.2^{\prime \prime} \mathrm{N} 76^{\circ} 57^{\prime} 0.7^{\prime}$ 'W, 22/27-XI-2013, en tronco, Y.A. Mera, D. Delgado, L. Ortiz, R. Sinisterra y C. Arturo col. (Unicauca); 1 worker. Same data (Unicauca).

Comments. This species was previously known for Argentina, Brazil, and Paraguay (Cuezzo 1998, Wild 2007, Calixto 2013). The present record extends the distribution of Pheidole bruchi $2924 \mathrm{Km}$ to the North from the northernmost record in Santa Catalina, Argentina, reported by Bruch (1914).

\section{Pheidole bruesi Wheeler, 1911}

Material Examined. 1 queen. Colombia: Putumayo: territorio Kofán, 1000 m, 23-IX-1998, E. González col. (IAvH). 4 workers. Same data (IAvH). 1 soldier. territorio Kofán, 1000 m, 13-VIII-1998, E. González col. (IAvH). 1 worker. Vaupés: Caparú, Estación Mosiro-Itajura, 60 m, 14' $\mathrm{N}$ 69³'W, 4/11-III-2003, malaise, J. Pinzón col. (IAvH). 1 soldier. Nariño: Ipiales: Territorio Kofán, 700 m, 0`30’7’N 77¹3’43’W, 27-IX-1998, manual sampling with tuna, E. González col. (IAvH). 
Comments. This species was previously known for Brazil, French Guiana, and Lesser Antilles (Oliveira et al. 2009, Groc et al. 2013, Wilson 2003). The present record extends the distribution of Pheidole bruesi $990 \mathrm{Km}$ to the Northwest from the closest record in Amazonas, Brazil, reported by Vasconcelos et al. (2010).

\section{Pheidole cataractae Wheeler, 1916}

Material Examined. 1 soldier. Colombia: Valle del Cauca: Dagua: 3³9'25.59'N 76²1'24.52”, 14/16-V-2015 (CBUMAG). No more data.

Comments. Pheidole cataractae was previously known from Brazil, Ecuador, Guyana, and Peru (Wheeler 1916, Mertl et al. 2009, Bezdeckova 2015, Souza et al. 2015,). The present record extends the distribution of this species $480 \mathrm{Km}$ to the North from the closest record in Ecuador, reported by Mertl et al. (2009).

\section{Pheidole dolon Wilson, 2003}

Material Examined. 1 soldier, 1 worker. Colombia: Amazonas: Leticia: vía Tarapacá Varzea, 253’21.93”S 6944’30.50”W, 2002, Barriga col. (ICN).

Comments. Pheidole dolon was previously known from Bolivia, French Guiana, and Peru (Economo et al. 2015, Groc et al. 2009, Prado et al. 2019, Wilson 2003). The present record is located $1069 \mathrm{Km}$ to the North from the type locality in Peru, reported by Wilson (2003).

\section{Pheidole kuna Wilson, 2003}

Material Examined. 1 worker. Colombia: Cauca: Piamonte: 300m, 17'12.57”N 76¹9'19.43”W, 19/22-V-2014, winkler, Y.A. Mera, D. Delgado, L. Ortiz, R. Sinisterra and C. Arturo col. (Unicauca). 2 soldiers. Piamonte: Vda. La Leona, $284 \mathrm{~m}, 1^{\circ} 6^{\prime} 24.51^{\prime \prime} \mathrm{N}$ 76² ${ }^{\prime} 52.26$ ”W, 19/22-V-2014, manual sampling, Y.A. Mera, D. Delgado, L. Ortiz, R. Sinisterra and C. Arturo col. (UniCauca). 1 soldier. Piamonte: 300 m, 13/23-V-2014, manual sampling, Y.A. Mera, D. Delgado, L. Ortiz, R. Sinisterra and C. Arturo col. (Unicauca). 1 worker. Piamonte: $300 \mathrm{~m}, 1^{\circ} 7^{\prime} 12.57^{\prime} \mathrm{N} 76^{\circ} 19^{\prime} 19.43$ "W, 13/23-V2014, manual sampling, Y.A. Mera, D. Delgado, L. Ortiz, R. Sinisterra and C. Arturo col. (Unicauca).

Comments. This species was previously known from Panama (Wilson 2003). The present record extends its distribution $979 \mathrm{Km}$ to the South from the closest record in Panama, reported by Wilson (2003). This is the first record of Pheidole kuna for South America.

\section{Pheidole leonina Wilson, 2003}

Material Examined. 1 soldier, 1 worker. Colombia: Amazonas: Río Ayo, 97 m, 26'45.82”'S 6946’40.32” W, 01-IV-2002, F. Quevedo col. (ICN). 1 soldier. same data (ICN)

Comments. Pheidole leonina was previously known from Brazil and Peru (Oliveira et al. 2009, Wilson 2003). The present record extends the distribution of this species $916 \mathrm{Km}$ to the North from the most northern record of the species in Acre, Brazil, reported by Oliveira et al. (2009).

\section{Pheidole socrates Forel, 1912}

Material Examined. 1 soldier. Colombia: Nariño: Barbacoas: RNN El Pangán, 1469m, 1¹9’43” N 455' W, 06-VIII-2006, manual sampling, A. Miranda and O. Reyes col. (IAvH); 4 workers. Barbacoas: RNN El Pangán, 1189 m, 1²0'8” N 785'20”'W, 30-VII/01-VIII-2006, pitfall, A. Miranda and O. Reyes col. (IAvH).

Comments. Pheidole socrates was previously known from Bolívia, Brazil, Ecuador, French Guiana, Guyana, Lesser Antilles, Mexico, Panama, Suriname, and Trinidad and Tobago (Forel 1912, Fernández \& Sendoya, 2004, LaPolla \& Cover 2005, Mamani-Mamani et al. 2012, Guenard et al. 2017). The present record is located $201 \mathrm{Km}$ to the North from the closest record in Ecuador, reported in antmaps.org (Guénard et al. 2017).

\section{Pheidole midas Wilson, 2003}

Material Examined. 1 worker, 1 soldier. Colombia: Bolívar: San Juan Nepomuceno: 956’56.49’'N 755’1.47’W, 06/08-XI-2014 (CBUMAG); 3 soldier, 4 workers. Colombia: Bolívar: San Juan Nepomuceno: Arroyo Grande, 176 m, 956’23.532”N 75¹0'7.622”W, 03-II-2016, pitfall, R. Achury col. (CBUMAG); 1 worker, 1 soldier. Antioquia: San Luis: El Refugio, Parque Ecológico Cañón del Río Claro, 515 m, 554’3.39’'N 7451’23.85’'W, 10-IV-1998, A. Amarillo col. (ICN).

\section{Comments.}

Pheidole midas was previously known from Brazil, Ecuador, French Guiana, Lesser Antilles, Panama, Peru and Venezuela (Alonso et al. 2001, Basset et al. 2012, Fichaux et al. 2019, Filho et al. 2003, Mertl et al. 2010, Prado et al. 2019, Wilson 2003). The record from San Juan Nepomuceno is located $526 \mathrm{Km}$ to the Southeast from the closest record in Panama reported by Guénard et al. (2017).

Pheidole midas was previously identified as $P$. veletis Wilson, 2003, as both species are differentiated by very subtle traits that can lead to misidentification. However, Pheidole midas can be differentiated by the dorsal surface of the head that is largely smooth and relatively shining, with notable foveas and a large-celled patch of rugoreticulum present to the side and behind each antennal fossa (Wilson 2003), while $P$. veletis with the dorsal surface of the head dull and rough, and carinulae originating on frontal lobes extend halfway between level of eye and occiput.

\section{Pheidole wallacei Mann, 1916}

Material Examined. 4 workers. Colombia: Amazonas: Río Ayo, 1-V-2002, primary forest, F. Quevedo col. (ICN). No more data.

Comments. Pheidole wallacei was previously known from Brazil and French Guiana (Mann 1916, Groc et al. 2009). The present record is located about $1000 \mathrm{Km}$ to the Northwest from the closest record in Rondonia, Brazil (Mann 1916). 
Pheidole zoster Wilson, 2003

Material Examined. 1 soldier, 3 workers. Colombia: Cauca: Sabanetas, La Romelia-El Tambo, El Ensueño, Km 2, 1938 m, $2^{\circ} 33^{\prime} 09.9$ 'N 76 51'40.3”'W. No more data. (IAvH).

Comments. Pheidole zoster was previously known from Brazil and Peru. The present record is located at approximately $1312 \mathrm{Km}$ to the North from the closest record in Peru.

\section{Rogeria procera Emery, 1896}

Material Examined. 2 workers. Colombia: Guaviare: Calamar Chiribiquete Cerro Campana, 306 m, 01¹7’10.5”N 72³7’32.1”W, 3/6-III-2018, Pitfall white sand savannah, Tree trunk, D. Luna and A. Pinzon col. (ICN); 1 worker. Calamar Chiribiquete Cerro Campana, 306 m, 01¹6’49.9'N 72³7'53.2”W, 3/6-III-2018, Winkler, Varillal, rocky leaf litter, D. Luna and A. Pinzón col. (ICN).

Comments. This species was previously known from Guyana (Lapolla and Fisher 2006), Brazil (Pará and Amazonas), and Salta, Argentina (Badano et al. 2005). The present record is $1483 \mathrm{Km}$ to the West from the closest record in Manaus, Brazil (Kugler 1994).

\section{Rogeria subarmata (Kempf, 1961)}

Material Examined. 1 worker. Colombia: Vaupés: Cgto. Pacoa, Comunidad Morroco, Cuenca Rio Cauauari, Cerro Morroco, 195 m, $00^{\circ} 08^{\prime} 19.2$ 'N 7057'01.3”'W, 27-II-2018, manual firm floor forest, leaf litter, D. Luna and W. Gómez col. (ICN).

Comments. This species has been extensively reported for Brazil (Pará, Bahia, Minas Gerais, São Paulo, Rio de Janeiro, Espírito Santo). Furthermore, it has been recorded for French Guiana (Gibernau et al. 2007), Venezuela, and Ecuador (Ryder et al. 2010). The present record is located $583 \mathrm{Km}$ to the Northeast from the closest record in Ecuador (Ryder et al. 2010).

\section{Talaridris mandibularis Weber, 1941}

Material Examined. 1 worker. Colombia: Caquetá: PNN Serranía de Chiribiquete, $0^{\circ} 42^{\prime} \mathrm{N} 72^{\circ} 42^{\prime} \mathrm{W}, 30-\mathrm{I}-2000$, Winkler, F. Quevedo col. (ICN).

Comments. This species was previously known from Brazil, French Guiana, Guyana and Venezuela (Brown \& Kempf 1960, Weber 1941). This species is listed in Fernández et al. (2019) without precise locality; this is the first geographical report and confirmation of the species in the country. The present record is located $794 \mathrm{Km}$ to the West from the closest record in Venezuela (Lattke 1992).

\section{Ponerinae}

\section{Leptogenys rasila Lattke, 2011}

Material Examined. 1 worker. Colombia: Cauca: Popayán, Centro de estudios vegetales La Rejoya, 1770 m, 2³1'02'N 76³5'34'W, 21,22-IX2019, Winkler, D. Cubillos col. (CBUMAG).

Comments. This species was previously known from Ecuador (Lattke 2011). The present record is located $463 \mathrm{Km}$ to the northeast from the closest record in Ecuador (Salazar et al. 2015).

\section{Discussion}

In the Neotropical region, the number of genera and species currently known is 131 and 3463, respectively (Fernández et al. 2019), and approximately $81 \%$ of these genera are registered in Colombia (Fernández et al. 2019). The thirty-one new ants registered here raise the number of specific taxa known from Colombia to 1197 species. This species richness represents more than one third $(\sim 34 \%)$ of the known Neotropical species.

In the "Hormigas de Colombia" book, Fernández et al. (2019) reported 50 genera and 535 Myrmicinae species for Colombia, but a recent phylogenetic work added two more genera, Mycetomoellerius Solomon et al., 2019 and Paratrachymyrmex Solomon et al., 2019 replacing the former genus Trachymyrmex Forel, 1893 (Solomon et al. 2019). The thirty-one new records we provide here increase the Myrmicinae composition to 560 species. This species richness is relatively higher than that of countries such as Costa Rica (535 native species sensu antmaps.org (Janicki et al. 2016) or 539 according to Antweb), whose forests have been widely sampled resulting in a much better-known ant fauna. Within the Myrmicinae, the genus Pheidole is the most species-rich, with more than 1100 species throughout the world. Currently, there are 620 species of Pheidole known for the Neotropical region, with just two invasive species, Pheidole indica Mayr, 1879 and Pheidole megacephala (Fabricius, 1793). After Guerrero et al (2018), the species richness of Pheidole was 118 species, including Pheidole indica (there reported for the first time for Colombia) and Pheidole megacephala (previously reported by Chacón de Ulloa \& Achury 2011). Here, we provide ten new species records elevating the species richness of Pheidole in Colombia up to 128 species. The species richness of Pheidole in Colombia is almost half of the specific richness reported for the Mesoamerican wet forests (Longino 2019), however, the records for Colombia could equal or exceed those numbers, due to the study of Pheidole specimens coming from different types of forests, both from lowlands (e.g., tropical dry forest and sub-xerophytic formations) as Andean and sub-paramun forests.

Among the thirty-one new ants for Colombia, we found species whose updated distributions may be the basis for present or future biogeographic questions. We recorded for the first time five species that were previously known from Central America, Azteca quadraticeps, Azteca snellingi, Eurhopalothrix schmidti, and Eurhopalothrix xibalba and Pheidole kuna. The two Azteca species extend their distribution to the northernmost area of South America, both with populations inhabiting the lowlands of the Sierra Nevada de Santa Marta (northern Colombia). 
In general, Azteca species have great dispersal capacity, which for both cases could have allowed them to reach a wide distribution dispersing through the Darien mountain range and the favorable habitat that extends along the Caribbean plain, until reaching the lowlands of the mountainous massif. In the case of the Eurhopalothrix species registered here, both present an Andean distribution, one in the eastern Cordillera (Eurhopalothrix schmidti) and the other in the central Cordillera (Eurhopalothrix xibalba). Eurhopalothrix schmidti was collected at $2000 \mathrm{~m}$ of altitude, matching the altitude distribution in Mesoamerica that ranges from $1100 \mathrm{~m}$ to $2200 \mathrm{~m}$, while Eurhopalothrix xibalba was collected at high elevations, above $1700 \mathrm{~m}$ within the altitudinal range of this species in Central America, from $50 \mathrm{~m}$ to above $1600 \mathrm{~m}$ (Longino 2013a). On the other hand, Pheidole kuna, spreading through the Chocoan biogeographic region, adding to other arthropods from the Chocó-Darién province (Morrone 2014).

The records of Fulakora agostii in Colombia expands its distribution from Brazil to almost $4500 \mathrm{~km}$ north-west of South America. The first records of Fulakora agostii come from the Brazilian Atlantic Forest (Lacau \& Delabie 2002), however, the Fulakora agostii population in Colombia comes from the Andean landscape at 1500 $\mathrm{m}$ altitude. The Colombian Andean and the Brazilian Atlantic forest populations are allopatric, with a large discontinuity in its distribution, as currently there are no records in the Amazon basin, despite the abundant sampling in the Brazilian Amazon. Several hypotheses may explain the current distribution range of this species, but only two will be outlined. First, its occurrence in those two kinds of forests could suggest wide ecological plasticity to adapt to contrasting habitats. The second hypothesis would take into account the taxonomic validity of the Andean population, in this sense, this Andean population could correspond to an undescribed different evolutionary lineage. Although the diagnostic characteristics in this population match completely those offered by Lacau \& Delabie (2002) it is necessary to carry out molecular analysis at the population level in F. agostii to try and differentiate between these hypotheses.

Recently, Guerrero et al. (2018) indicated that the growing knowledge of Colombian ant diversity may be due to factors such as the possibility of sampling in forests under the protection of the National Parks Unit, using sampling techniques that produce large volumes of biological material (e.g. Winkler extractors). However, the possibility of sampling in areas that were previously in armed conflict has also had a positive effect on myrmecological studies in the country. In this case, $50 \%$ of the new reports here come from forested areas where the armed conflict has completely ceased (e.g., all Octostruma species and five species of Pheidole recorded here); the other $50 \%$ correspond to ants that were collected in forests protected by the network of national parks or inside indigenous reserves. These factors expose the importance of collecting in unsampled areas for 1) better resolution of the distribution of biota and to support stronger biogeographic hypotheses, 2) access to more populations of known species to have a clearer picture of their genetic variability, tokogenetic relationships of these populations (i.e., phylogeography) and understanding the phenotypic variability of some species, and 3) increase records within national biological collections to help complement biodiversity inventories and decision-making by government entities at different spatial scales.

\section{Acknowledgments}

Special thanks to Dr. Rodrigo Feitosa for his comments on the early version of the manuscript. Thanks to John Lattke for reviewing the English and comments to improve the quality of the manuscript. Many thanks to two anonymous reviewers for the invaluable comments and corrections that improved the scientific quality of this contribution. To Dr. Dimitri Forero and Dr. John Cesar Neita for their help in facilitating the access to the ants deposited in the MPUJ and IAvH collections. This is contribution No. 14 in the series Ants of Colombia. This article is part of the master's work of the first author: Taxonomy and Distribution of Pheidole ants (Formicidae: Myrmicinae) in Colombia. We thank the Office of "Editorial Unimagdalena" for the financial support to pay the publication fees. This is scientific contribution No.17 from the Colecciones Biológicas at the Universidad del Magdalena (CBUMAG).

\section{Author Contributions}

Emira I. García contributed in the preparation of the manuscript, as well as to the identification of several ant species and the collection of distribution data from museums and biological collections. Also, she critically reviewed the different versions of this manuscript, incorporating arguments and hypotheses contained in the latter.

María C. Tocora contributed to the preparation of the manuscript, as well as to the identification of ant species and the collection of distribution data from museums and biological collections. She reviewed and corrected the different versions of this manuscript.

Gian P. Fiorentino contributed to the preparation of the manuscript, as well as to the identification of ant species and the collection of distribution data from museums and biological collections. He reviewed and corrected the different versions of this manuscript.

Fernando Fernández contributed to the preparation of the manuscript, as well as to the identification of ant species and the collection of distribution data from museums and biological collections. He reviewed and corrected the different versions of this manuscript.

Mayron E. Escárraga contributed in the preparation of the manuscript, as well as in the identification of some ant species. He was responsible for managing electronic resources to calculate geographic distances and to refine the geographic coordinates of all records; he critically revised the first draft and the final version of the manuscript.

Roberto J. Guerrero contributed substantially in the preparation of the manuscript, as well as to the identification of several ant species and the collection of distribution data from museums and biological collections. He wrote and added intellectual arguments and hypotheses contained in the manuscript; moreover, critically reviewed and corrected the different versions of this one.

\section{Conflicts of Interest}

The authors of this manuscript declare that they have no conflict of interest regarding the publication of this manuscript. Likewise, each of them agrees with the opinions contained in this manuscript.

\section{Ethics}

All authors declare to be in compliance with all ethical stablished guidelines. 


\section{References}

ALONSO, L., KASPARI, M. \& ALONSO, A. 2001 Assessment of the Ants of the Lower Urubamba Region, Peru. In Urubamba: The biodiversity of a Peruvian rainforest (A. Alonso, F. Dallmeier \& P. Campbell, eds.). SI/MAB Biodiversity Program-Smithsonian Institution. p.87-93.

ANTWEB. 2020. https://www.antweb.org. (last accessed 26/06/2020)

AZORSA, F. \& SOSA-CALVO, J. 2008. Description of a remarkable new species of ant in the genus Daceton Perty from South America. Zootaxa 1749(1):27-38

BADANO, E.I., REGIDOR, H.A., NUNEZ, H.A., ACOSTA, R. \& GIANOLI, E. 2005. Species richness and structure of ant communities in a dynamic archipelago: effects of island area and age. J. Biogeogr. 32:221-227.

BASSET, Y., CIZEK, L., CUÉNOUD, P., DIDHAM, R.K., GUILHAUMON, F., MISSA, O., NOVOTNY, V., ØDEGAARD, F., ROSLIN, T., SCHMIDL, J., TISHECHKIN, A.K., WINCHESTER, N.N., ROUBIK, D.W., ABERLENC, H.P., BAIL, J., BARRIOS, H., BRIDLE, J.R., CASTAÑO-MENESES, G., CORBARA, B., CURLETTI, G., DUARTE DA ROCHA, W., DE BAKKER, D., DELABIE, J.H., DEJEAN, A., FAGAN, L.L., FLOREN, A., KITCHING, R.L., MEDIANERO, E., MILLER, S.E., GAMA DE OLIVEIRA, E., ORIVEL, J., POLLET, M., RAPP, M., RIBEIRO, S.P., ROISIN, Y., SCHMIDT, J.B., SØRENSEN, L. \& LEPONCE, M. 2012. Arthropod diversity in a tropical forest. Science 338(6113):1481-1484.

BOLTON, B. 1995. A new general catalogue of the ants of the world. Harvard University Press, Cambridge.

BOLTON, B. 2020. An online catalog of the ants of the world. Available from https://antcat.org. (last access in 12/03/2020).

BRANDÃO, C.R.F. 1991. Adendos ao catálogo abreviado das formigas da região Neotropical (Hymenoptera: Formicidae). Rev. Bras. Entomol. 35:319-412.

BRANSTETTER, M.G. \& SÁENZ; L. 2012. Las hormigas (Hymenoptera: Formicidae) de Guatemala. In Biodiversidad de Guatemala (E.B. Cano \& J.C. Schuster, eds.). Universidad del Valle de Guatemala, Guatemala, v.2, p.221-268

BROWN, W.L., Jr. \& KEMPF, W.W. 1960. A world revision of the ant tribe Basicerotini. Stud. Entomol. 3:161-250.

BROWN, W.L., Jr. \& KEMPF, W.W. 1969. A revision of the neotropical dacetine ant genus Acanthognathus (Hymenoptera: Formicidae). Psyche 76: 87-109.

BRUCH, C. 1914. Catálogo sistemático de los formícidos argentinos Rev. Mus. La Plata 19:211-234.

BRUCH, C. 1921. Estudios mirmecológicos. Rev. Mus. La Plata 26:175-211.

CALIXTO, J. 2013. Lista preliminar das espécies de formigas (Hymenoptera: Formicidae) do estado do Parana, Brasil. Tese de graduação, Universidade Federal do Paraná (UFPR), Curitiba.

CUEZZO, F. 1998. Formicidae. In Biodiversidad de artrópodos argentinos: una perspectiva biotaxonómica (Morrone, J.J. \& S. Coscarón, eds.). Ediciones Sur, La Plata, p.452-462.

DE ANDRADE, M.L. 2001. A remarkable Dominican amber species of Cylindromyrmex with Brazilian affinities and additions to the generic revision (Hymenoptera: Formicidae). Beitr. Entomol. 51:51-63.

ECONOMO, E.P., KLIMOV, P., SARNAT, E.M., GUÉNARD, B., WEISER, M.D., LECROQ, B. \& KNOWLES, L. L. 2015. Global phylogenetic structure of the hyperdiverse ant genus Pheidole reveals the repeated evolution of macroecological patterns. Proceedings of the Royal Entomological Society of London. Series B 282:20141416, p.10

FERNÁNDEZ, F., GUERRERO, R.J. \& DELSINNE, T.D. 2019. Hormigas de Colombia. 1 ed. Universidad Nacional de Colombia, Bogotá.

FERNÁNDEZ, F., \& SENDOYA, S. 2004. Lista sinonímica de las hormigas neotropicales (Hymenoptera: Formicidae). Biota Colombiana 5(1): 3-105.

FICHAUX, M., BECHADE, J., DONALD, A., WEYNA, J., DELABIE, J.H.C., MURIENNE, J., BARALOTO, C., \& ORIVEL, J. 2019. Habitats shape taxonomic and functional composition of Neotropical ant assemblages. Oecologia 189(2): 501-513.

FILHO, P.A.A., ANDRADE DO VALE, L.L., FERREIRA DE CARVALHO LAVO, M.T., RIBEIRO NETO, J.D., COELHO MELO, M.V., HITES, N., DE BISEAU, J.C. \& QUINET, Y.P. 2003. Biodiversity of the myrmecofauna (Hymenoptera: Formicidae) in a primary forest of the Serra de BaturitéCeará. Ciencias e Tecnologia 5(2): 17-29.
FOREL, A. 1912. Formicides néotropiques. Part III. 3me sous-famille Myrmicinae (suite). Genres Cremastogaster et Pheidole. Mem. Soc. Ent. Belga. 19:211-237.

GALVIS, J.P. \& FERNÁNDEZ, F. 2009. Ants of Colombia X. Acanthognathus with the description of a new species (Hymenoptera: Formicidae). Rev. Colomb. Entomol. 35(2):245-249.

GIBERNAU M., ORIVEL, J., DELABIE, J.H.C., BARABE, D. \& DEJEAN, A. 2007. An asymmetrical relationship between an arboreal ponerine ant and a trash-basket epiphyte (Araceae). Biol. J. Linn. Soc. Lond. 91:341-346.

GROC, S., ORIVEL, J., DEJEAN, A., MARTIN, J.M., ETIENNE, M.P., CORBARA, B., \& DELABIE, J.H.C. 2009. Baseline study of the leaf-litter ant fauna in a French Guianese forest. Insect. Conserv. Divers, 2(3):183-193.

GROC, S., DELABIE, J.H.C., FERNÁNDEZ, F., LEPONCE, M., ORIVEL, J., SILVESTRE, R., VASCONCELOS, H.L. \& DEJEAN, A. 2013. Leaflitter ant communities (Hymenoptera: Formicidae) in a pristine Guianese rainforest: stable functional structure versus high species turnover. Myrmecol. News 19:43-51.

GUERRERO, R.J., DELABIE, J.H.C. \& DEJEAN, A. 2010. Taxonomic contribution to the aurita group of the ant genus Azteca (Formicidae: Dolichoderinae). J. Hymenopt. Res. 19:51-65.

GUERRERO, R., FERNÁNDEZ, F., ESCÁRRAGA, M., PÉREZ-PEDRAZA, L., SERNA, F., MACKAY, W., SANDOVAL, V., VERGARA, V., SUÁREZ, D., GARCÍA, E., SÁNCHEZ, A., MENESES, A., TOCORA, M., \& SOSACALVO, J. 2018. New records of myrmicine ants (Hymenoptera; Formicidae) for Colombia. Revista Colombiana De Entomología, 44(2):238-259.

GUÉNARD, B., WEISER, M.D., GOMEZ, K., NARULA, N. \& ECONOMO, E.P. 2017. The Global Ant Biodiversity Informatics (GABI) database: synthesizing data on the geographic distribution of ant species (Hymenoptera: Formicidae). Myrmecol. News 24:83-89.

HARADA, A.Y. \& ADIS, J. 1998. Ants obtained from trees of a" Jacareuba"(Calophyllum brasiliense) forest plantation in Central Amazonia by canopy fogging: first results. Acta Amaz. 28(3):309-309.

JANICKI, J., NARULA, N., ZIEGLER, M., GUÉNARD, B. ECONOMO, E.P. 2016. Visualizing and interacting with large-volume biodiversity data using client-server web-mapping applications: The design and implementation of antmaps.org. Ecol. Inform. 32: 185-193

KEMPF, W.W. 1963. A review of the ant genus Mycocepurus Forel, 1893 (Hymenoptera: Formicidae). Stud. Entomol. 6:417-432

KEMPF, W.W. 1964. A revision of the Neotropical fungus-growing ants of the genus Cyphomyrmex Mayr. Part I: Group of strigatus Mayr (Hym., Formicidae). Stud. Entomol. 7:1-44.

KEMPF, W.W. 1975 (“1974”). Report on Neotropical Dacetine ant studies (Hymenoptera: Formicidae). Rev. Bras. Biol. 34:411-424.

KUGLER, C. 1994. A revision of the ant genus Rogeria with description of the sting apparatus (Hymenoptera: Formicidae). J. Hymenopt. Res. 3:17-89.

LACAU, S. \& DELABIE, J.H.C. 2002. Description de trois nouvelles espèces d'Amblyopone avec quelques notes biogéographiques sur le genre au Brésil (Formicidae, Ponerinae). Bull. Soc. Entomol. Fr. 107(1):33-41.

LAPOLLA, J.S. \& COVER, S.P. 2005. New species of Pheidole (Hymenoptera: Formicidae) from Guyana, with a list of species known from the country. T. Am. Entomol. Soc. 131:(3-4):365-374.

LAPOLLA, J.S. \& FISHER, B.L. 2006. Review of the ant genus Rogeria (Hymenoptera: Formicidae) in Guyana. Zootaxa 1330:59-68.

LATTKE J.E. 1985. Hallazgos de hormigas nuevas para Venezuela (Hymenoptera: Formicidae). Bol. Entomol. Venez. 4(10):82-84.

LATTKE J.E. 1991. Studies of Neotropical Amblyopone Erichson (Hymenoptera: Formicidae). Contributions in Science, 428:1-7.

LATTKE J.E. 1992. Estudios de hormigas de Venezuela (Hymenoptera: Formicidae). Bol. Entomol. Venez. 6:57-61

LATTKE, J.E. 2011. Revision of the new world species of the genus Leptogenys Roger (Insecta: Hymenoptera: Formicidae: Ponerinae). Arthropod Systematics and Phylogeny, 69(3):127-264.

LONGINO, J.T. 2007. A taxonomic review of the genus Azteca (Hymenoptera: Formicidae) in Costa Rica and a global revision of the aurita group. Zootaxa 1491:1-63 
LONGINO, J.T. 2013a. A review of the Central American and Caribbean Species of the ant genus Eurhopalothrix Brown and Kempf, 1961 (Hymenoptera, Formicidae), with a key to New World species. Zootaxa 3693:101-151.

LONGINO, J.T. 2013b. A revision of the ant genus Octostruma Forel 1912 (Hymenoptera, Formicidae). Zootaxa 3699(1):1-061.

LONGINO, J.T. 2013c. Ants of Nicaragua. https://sites.google.com/site/ longinollama/reports/ants-of-nicaragua (last access in 21/12/2019).

LONGINO, J.T. \& BRANSTETTER, M.G. 2018. The truncated bell: an enigmatic but pervasive elevational diversity pattern in Middle American ants. Ecography 42(2): 272-283.

LONGINO, J.T. 2019. Pheidole (Hymenoptera, Formicidae) of Middle American Wet Forest Zootaxa 4599(1):001-126.

MACKAY, W.P., MAES, J.M., FERNÁNDEZ, P.R. \& LUNA, G. 2004. The ants of North and Central America: the genus Mycocepurus (Hymenoptera: Formicidae). J. Insect Sci. 4 (27):01-07.

MAMANI-MAMANI, B., LOZA-MURGUIA, M., SMELTEKOP, H., ALMANZA, J.C., \& LIMACHI, M. 2012. Diversidad genérica de hormigas (Himenópteros: Formicidae) en ambientes de bosque, borde de bosque y áreas cultivadas tres Comunidades del Municipio de Coripata, Nor Yungas Departamento de La Paz, Bolivia. J. Selva Andina Res. Soc. 3(1):26-43.

MANN, W.M. 1916. The Stanford Expedition to Brazil, 1911, John C. Branner, Director. The ants of Brazil. Bull. Mus. Comp. Zool. 60:399-490.

MANN, W.M. 1922. Ants from Honduras and Guatemala. Proc. U. S. Natl. Mus. 61:1-54

MERTL, A.L., RYDER-WILKIE, K.T., \& TRANIELLO, J.F. 2009. Impact of flooding on the species richness, density and composition of Amazonian litter-nesting ants. Biotropica 41(5):633-641.

MERTL, A.L., SORENSON, M.D. \& TRANIELLO, J.F.A. 2010. Communitylevel interactions and functional ecology of major workers in the hyperdiverse ground-foraging Pheidole (Hymenoptera, Formicidae) of Amazonian Ecuador. Insectes Soc. 54:441-452.

MERTL, A. L., TRANIELLO, J. F., WILKIE, K. R., \& CONSTANTINO, R 2012. Associations of Two Ecologically Significant Social Insect Taxa in the Litter of an Amazonian Rainforest: Is There a Relationship between Ant and Termite Species Richness? Psyche 2012:1-12 doi:10.1155/2012/312054.

MORRONE, J.J. 2014. Biogeographical regionalisation of the Neotropical region. Zootaxa 3782 (1):1-110 http://dx.doi.org/10.11646/zootaxa.3782.1.1

MUNOZ, R.A.L. 2018. Mirmecofauna (Hymenoptera: Formicidae) de serapilheira em tres localides da mata Atlantica da Serra do Mar no estado do Parana. Mphil thesis Universidade Federal do Parana, p.55.

OLIVEIRA, M.A., DELLA LUCIA, T.M.C., MARINHO, C.G.S., DELABIE, J.H.C. \& MORATO, F.F. 2009. Ant (Hymenoptera: Formicidae) diversity in an area of the Amazon forest in Acre, Brazil. Sociobiology 54(1):243-267.
PRADO, L.P., FEITOSA, R.M., TRIANA, S.P., GUTIÉRREZ, J.A.M., ROUSSEAU, G.X., SILVA, R.A., SIQUEIRA, G.M., SANTOS, C.L.C., SILVA, F.V., SILVA, T.S.R., CASADEI-FERREIRA, A., SILVA, R.R., ANDRADE-SILVA, J. 2019. An overview of the ant fauna (Hymenoptera: Formicidae) of the state of Maranhão, Brazil. Pap. Avulsos Zool. 59:e20195938.

RIBEIRO, S., ESPIRITO SANTO, N., DELABIE, J.H.C. \& MAJER, J. 2013. Competition, resources and the ant (Hymenoptera: Formicidae) mosaic: a comparison of upper and lower canopy. Mycol. Prog. 18:113-120.

RYDER, K.T., MERTL, A. L. \& TRANIELLO, J.F.A. 2010. Species Diversity and Distribution Patterns of the Ants of Amazonian Ecuador. PLoS ONE 5(10):1-12.

SALAZAR, F., REYES-BUENO, F., SANMARTIN, D. \& DONOSO, D.A. 2015. Mapping continental Ecuadorian ant species. Sociobiology 62(2):32-162.

SOLOMON, S.E., RABELING, C., SOSA-CALVO, J., LOPES, C.T., RODRIGUES, A., VASCONCELOS, H.L. \& SCHULTZ, T.R. 2019. The molecular phylogenetics of Trachymyrmex Forel ants and their fungal cultivars provide insights into the origin and coevolutionary history of 'higher-attine' ant agriculture. Syst. Entomol. 44(4):939-956.

SOUZA, J.L.P., BACCARO, F.B., LANDEIRO, V.L., FRANKLIN, E., MAGNUSSON, W.E., PEQUENO, P.A.C.L., \& FERNANDES, I.O. 2015 Taxonomic sufficiency and indicator taxa reduce sampling costs and increase monitoring effectiveness for ants. Divers. Distrib. 22(1):111-122.

VASCONCELOS, H.L., VILHENA, J.M., FACURE, K.G., \& ALBERNAZ, A.L. 2010. Patterns of ant species diversity and turnover across $2000 \mathrm{~km}$ of Amazonian floodplain forest. J. Biogeogr. 37(3):432-440.

VICENTE, R.E., DAMBORZ, J. \& ROCHA BARRETO, M. 2011. New distribution record of Daceton boltoni Azorsa and Sosa-Calvo, 2008 (Insecta: Hymenoptera) ant in the Brazilian Amazon. Check List 7(6):878-879.

WEBER, N.A. 1941. Four new genera of Ethiopian and Neotropical Formicidae. Ann. Entomol. Soc. Am. 34:183-194.

WEBER, N.A. 1968. Tobago Island fungus-growing ants (Hymenoptera: Formicidae). Entomological News 79:141-145. [1968-06-07]

WHEELER, W.M. 1916. Ants collected in British Guiana by the expedition of the American Museum of Natural History during 1911. Bull. Am. Mus. Nat. Hist. 35:1-14.

WHEELER, G.C. 1949 (“1948”). The larvae of the fungus-growing ants. Am. Midl. Nat. 40:664-689.

WILD, A.L. 2007. A catalogue of the ants of Paraguay (Hymenoptera: Formicidae). Zootaxa 1622(1):1-55.

WILSON, E.O. 2003. Pheidole in the New World: a dominant, hyperdiverse ant genus. v.1. Harvard University Press, Cambridge.

Received: $21 / 07 / 2020$

Revised: $18 / 08 / 2020$

Accepted: 27/08/2020

Published online: 30/09/2020 